\title{
Pandemia de Coronavirus. Qué estamos haciendo...
}

\section{Coronavirus pandemic. What are we doing...}

\author{
José Carlos Herrera-García*
}

*Hospital Ángeles, Puebla, México.

El descubrimiento de la nueva neumonía por Coronavirus en Wuhan, la cual se ha extendido en todo el mundo, nos ha dejado ver una nueva etapa de la vida humana, la letalidad del virus nos ha demostrado lo frágiles que somos frente a retos biológicos; esta pandemia con más de 600 mil muertos nos arroja la necesidad de pensar acerca de la vida que llevamos y la forma en que la llevamos, primeramente a la comunidad médica a forzarnos a administrar múltiples tratamientos para disminuir el sufrimiento del enfermo al no tener aún un tratamiento dirigido o una vacuna eficaz. La mortalidad de los casos con distrés respiratorio que acuden a los servicios de urgencias es un reto diario para los médicos neumólogos y no neumólogos, repasando en nuestro cerebro la fisiopatología del virus, su efecto hiperinflamatorio y formación de coágulos que alteran la adecuada funcionalidad de la membrana alvéolo capilar, causando varios tipos de hipoxemia que llevan al enfermo a un estado de choque multisistémico y muerte.

Llevamos más de cinco meses luchando contra esta adversidad y debemos detenernos a pensar en toda la información que nos ha dejado, como implementar medicamentos no autorizados y confiar en el estado inmune del paciente, que le permitirá salir adelante de la enfermedad. Cabe mencionar que existen medicamentos que ya han sido descritos como coadyuvantes, como la azitromicina, un medicamento capaz de inhibir la actividad de la IL-6 y TNF, antipiréticos como el paracetamol que sólo disminuyen los síntomas de los pacientes, la anticoagulación y el uso de rivaroxabán/apixabán con excelentes respuestas frente a la carencia de la enoxaparina en algunas poblaciones. El oxígeno es un revulsivo en la enfer-

Correspondencia:

Dr. José Carlos Herrera-García

Hospital Ángeles, Puebla, México.

Correo electrónico: jchg10@yahoo.com.mx

Trabajo recibido: 23-VII-2020; aceptado: 18-VIII-2020.

Citar como: Herrera-García JC. Pandemia de Coronavirus. Qué estamos haciendo... Neumol Cir Torax. 2021; 80 (1): 68-69. https://dx.doi. org/10.35366/99458 medad que permite que los casos se recuperen, lo cual es un factor definitivo que ha obligado a darle el lugar que merece a la oximetría como el quinto signo vital, nunca tomado tan en cuenta como hasta ahora, en esta pandemia. Durante el tratamiento, nos tenemos que ayudar de medicamentos biológicos que inhiben la respuesta de las citocinas, como tocilizumab y ruxolitinib, a pesar de ser medicamentos sin suficiente sustento científico en estudios controlados, pero sí en series de casos. Durante la pandemia, cabe mencionar que la hipertensión y la obesidad son los factores de riesgo más importantes para desarrollar una neumonía grave, así como la carga viral a la que se expone el paciente y no así en los pacientes con enfermedad autoinmune, que de cierta manera hemos visto como protección por los tratamientos que toman y que no permite una respuesta exagerada de la inflamación. Otros factores relacionados son: sobrepeso; diabetes; hipotiroidismo; cáncer; insuficiencia renal; EPOC; etcétera. Dichas comorbilidades han ido incrementando de manera exponencial la mortalidad. Después de describir los tratamientos y la visión de los pacientes con coronavirus, es importante resaltar que las medidas sanitarias y el cubrebocas son las armas más baratas para detener la propagación del virus en cualquier circunstancia donde nos vemos involucrados, tomando en cuenta que la misma sociedad tiene que tomar el timón y ser empática con los grupos vulnerables.

En cuanto al diagnóstico, sigue siendo el estándar de oro la prueba de PCR, hasta el momento la única avalada para determinar la infección por coronavirus; los anticuerpos y las pruebas rápidas aún no están listas para ser tomadas en cuenta como diagnósticos, tal vez para seguimientos o forma de adquirir anticuerpos, pero sabemos que no son una fuente confiable en el diagnóstico. No me queda más que seguir en la lucha, con el miedo, entusiasmo, estrés, angustia y alegría en esta etapa que nos ha tocado vivir, donde nuestras familias sufren día a día la posibilidad de contagiarnos, pero todos juntos tendremos que salir adelante luchando codo a codo para lograr domar este nuevo desafío, sin olvidar que desgraciadamente tenemos un sistema de salud que ha sido superado y 
tener que conformarnos, por el momento, con el no uso de medicamentos como azitromicina, cloroquina/hidroxicloroquina, lopinavir/ritonavir, ivermectina, tocilizumab y ruxolitinib, sobre los cuales la autoridad sanitaria ha tomado la postura de no seguir prescribiéndolos, además, la poca empatía de los ciudadanos nos hace pensar que no se ve para cuándo podamos levantarnos y dar un fin a esta pandemia. ${ }^{1-5}$

\section{REFERENCIAS}

1. Mclntosh K. Coronavirus disease 2019 (COVID-19): Epidemiology, virology, clinical features, diagnosis, and prevention. UpToDate. 2020.

2. Ai T, Yang Z, Hou H, Zhan C, Chen C, Lv W, et al. Correlation of chest CT and RT-PCR testing for coronavirus disease 2019 (COVID-19) in
China: a report of 1014 cases. Radiology. 2020;296(2):E32-E40. doi: 10.1148/radiol.2020200642.

3. Tang N, Bai H, Chen X, Gong J, Li D, Sun Z. Anticoagulant treatment is associated with decreased mortality in severe coronavirus disease 2019 patients with coagulopathy. J Thromb Haemost. 2020;18(5):10941099. doi: 10.1111/jth.14817.

4. Buonaguro FM, Puzanov I, Ascierto PA. Anti-IL6R role in treatment of COVID-19-related ARDS. J TransI Med. 2020;18(1):165. doi: 10.1186/ s12967-020-02333-9.

5. Mehta P, McAuley DF, Brown M, Sanchez E, Tattersall RS, Manson JJ; HLH Across Speciality Collaboration, UK. COVID-19: consider cytokine storm syndromes and immunosuppression. Lancet. 2020;395(10229):1033-1034. doi: 10.1016/S0140-6736(20)30628-0.

Conflicto de intereses: El autor declara no tener conflicto de intereses. 